\title{
IAMJ
}

INTERNATIONAL

AYURVEDIC

MEDICAL JOURNAL

\section{CRITIQUE ON JALODARARI RASA - A MIGHTY HEPATOPROTECTOR}

\author{
$\underline{\text { Ayesha Zama }}^{1}, \underline{\text { Ravi. R. Chavan }}{ }^{2}$
}

${ }^{1}$ Second Year PG Scholar, ${ }^{2}$ Professor \& HOD

Department of Rasashastra and Bhaishajya Kalpana, T.G.A.M.C \&H, Ballari, Karnataka, India

Corresponding Author: Ayeshazama786@gmail.com

\section{https://doi.org/10.46607/iamj1809112021}

(Published Online: November 2021)

Open Access

(C) International Ayurvedic Medical Journal, India

Article Received: 05/10//2021 - Peer Reviewed: 27/10/2021 - Accepted for Publication: 06/11/2021

\section{Check for updates}

\begin{abstract}
Ayurveda is the oldest methodical branch of knowledge that speaks its reality in the sketch of philosophy. It comprises most scientific milieu of derivation. As per ancient Ayurveda scholars for getting a desirable outcome of any medication, it should be precisely analysed before prescribing to the patient. There are several classical formulations successfully practised by Ayurveda physicians for treating various ailments, and also there are few unexplored but potent formulations that need the attention of practitioners to come to light. The present study is based to collaborate various references as well as the Pharmacological importance and mechanism of action of a distinctive hepatoprotection Jalodarari Rasa. The most common manifestation of liver dysfunction is ascites, and the most common cause of ascites is liver disease. Ascites is the accumulation of fluid in the peritoneum. Despite advanced medical facilities still, there is no definite treatment that cures a patient of ascites completely. The modern treatments only provide provisional relief with time dependant recurrence but, the fluid gets collected in the abdominal cavity repeatedly. In such cases, Ayurvedic treatment gives relief without any side effects and can be correlated with Jalodara, mentioned in Ayurvedic medical science.

Jalodarari Rasa is a herbomineral preparation that is depicted in Bhaishajya Ratnavali Udararogaprakarana, its fundamental constitution being Jayapala, Tamra bhasma, pippali, maricha which are all having lekhanapachana-bhedana action and thereby useful to evacuate the excess accumulated fluid which is needed to counteract Jalodara. Hence, here an attempt has been made to address the detailed review of Jalodarari rasa.
\end{abstract}


Keywords: Ascites, hepatoprotective, Ayurveda

\section{INTRODUCTION}

Udararoga is swedavaha and ambuvaha srotodushti vikara due to Jataragnimandhyata, pranavayu and apanavayu dushti. Among the Tridosha, the prakupita vata gets accumulated in udara between the twak and mamsa leading to shotha; this is being termed as Udararoga.

Due to obstruction of swedavaha, ambuvaha srotas excessive accumulation of fluid, especially in peritoneal cavity occurs. Along with the aggravated vata, agni which is manda also causes Udararoga. Further, it vitiates Prana, Apana and ultimately causes the accumulation of Udaka in the body mainly in Udara, which is a cardinal feature of Jalodara. Jalodara is considered as a disease, instead of a symptom or a sign of another disease. In Ayurveda, types of udara roga are mentioned and every udararoga finally gets converted to Jalodara.

Ascites can be considered in Ayurveda under the broad spectrum of Udararoga. Ascites is a gastroenterological term for the accumulation of fluid in the peritoneal cavity that exceeds $25 \mathrm{ml}$. Ascites occurs when there is a disruption in the pressure forces between intravascular and extravascular fluid spaces, which allows extravascular fluid to accumulate in the anterior peritoneal cavity. Chronic liver diseases are disease process of the liver which involves progressive destruction and regeneration of liver parenchyma leading to functional and structural changes in form of fibrosis and cirrhosis. It consists of a wide range of liver pathologies which includes inflammation, reduction of size, polycystic liver disease and hepatocellular carcinoma. Finally, it decreases the liver function combined with portal hypertension to cause ascites symptoms. Portal hypertension thus can be considered as the main contributor to ascites but the exact mechanism behind this is not completely understood. The rise in portal blood pressure with a decrease in albumin may be the culprit for the formation of pressure gradient resulting in Abdominal ascites. Ayurveda is traditionally skilful and treated liver diseases for centuries and the drug toxicity appears to be less as compared to conventional medicine. Ayurveda treatment could be a potentially safe and effective complement in numerous liver diseases, it can be presumed that Ayurveda treatment blocks the fibrogenesis of the liver and regenerate hepatocytes. If replicated in a clinical trial then Ayurveda medicine could represent a promising tool to postpone the need for liver transplantations, increase in QOL of patients with cirrhosis, and reduce overall treatment costs of ALD patients.

Nityavirechana is the line of treatment in Udararoga and hence virechana aushadas are the first choice, virechana checks improper jatharagni and dhatvagni. It has laxative action which helps to eliminate toxins out of the body, which is caused due to chronic constipation in Jalodara. Here in the present study, Jalodarari rasa has been selected which has ingredients that can break down the root pathology of jalodara, by serving as nityavirechana as well as lekhaniya in action, in addition, it does kleda shoshana of various excess snigdha dravyas present in the body. This formulation is quoted in Udara roga prakarana of Bhaishajya Ratnavali, also in other rasashastra classical texts like Rasendra sara sangraha, Rasachandamshu, Rasakamadhenu, Yogaratnakara, Rasarajasundara, Bruhatyogatarangini and Rasamanjari, all depicting similar drug design. Ascites is a disease that has been described extensively in Ayurvedic literature along with medical treatment and surgical procedures related to the management of this condition. Diet restriction is an important feature of the management of this condition. Ayurvedic management with drugs such as provocation of digestion, daily therapeutic purgation, a stimulant for hepatic function and only milk diet that acts on the root of the pathology of ascites and by breaking down of pathogenesis gives good result in ascites. 


\section{INGREDIENTS AND PREPARATION OF JALODARARI RASA}

Table 1:

\begin{tabular}{|l|l|l|}
\hline Ingredients & Bot. Name & Quantity \\
\hline Pippali & Piper longum & 1 tola \\
\hline Maricha & Piper Nigrum & 1 tola \\
\hline Tamra & Cuprum & 1 tola \\
\hline Haridra & Curcuma longa & 1 tola \\
\hline Jayapala & Croton tigilum & 4 tola \\
\hline Snuhi & Euphorbia nerifolia & Q. S \\
\hline
\end{tabular}

Fine powder of the above ingredients is grounded with the latex of Snuhi for one day. Then it is made into paste and pills are prepared of nishka pramana.

DOSAGE-As mentioned in various classical rasashastra textbooks, dosage for jalodarari ras is 1 nishka pramana i.e $3 \mathrm{gms}$, which as per recent scholars who write down that 1 nishka pramana is not the appropriate dose for present era individuals who possess avara satva, so it's recommended to take1-2 ratti dose.

ANUPANA - No specific anupana is mentioned for this formulation. But as Jayapala is one of the components, sheetala jala can be administered as anupana. It's recommended to take one vati in the morning and after rechana or in case of excess rechana, dadhi anna is advised for intake, which is considered hita for stambhana. Also, as the day ends mudgayusha is advised as pathya for the individuals with jalodara.

1.PIPPALI ${ }^{2,3}$ - Species of the genus piper are among the important medicinal plants used in various systems of medicine. Piper longum L. (Piperaceae), commonly known as long pepper.

Table 2: Properties

\begin{tabular}{|l|l|}
\hline Rasa & Katu \\
\hline Guna & Laghu, snigdha, tikshna \\
\hline Veerya & Anushna sheeta \\
\hline Vipaka & Madhura \\
\hline Dosha & Kaphavata shamaka \\
\hline Rogaghnata & Udarashula, gulma, yakritvikara, Pleehavriddhi, krimiroga, hriddourbalya etc \\
\hline
\end{tabular}

The fruit extract improved the regeneration process by restricting fibrosis but offered no protection against acute damage or cirrhotic changes in rodents. It has been reported to possess antiasthamatic, antiinflammatory, hepatoprotective, hypercholesterolemic and immunomodulatory activities. It contains various alkaloids like piperine, piperlongumine, piperlonguminine etc which helps in the regeneration of hepatocytes. Piperine was found to enhance the bioavailability of structurally and therapeutically diverse drugs, possibly by modulating membrane dynamics due to its easy partitioning and increase in permeability of other drugs. It was suggested that piperine might be inducing alteration in membrane dynamics and permeation characteristics, along with induction in the synthesis of proteins associated with the cytoskeletal function, increasing the small intestine absorptive surface, thus assisting efficient permeation through the epithelial barrier. Studies also show that piperine enhances serum concentration, the extent of absorption and bioavailability of curcumin with no adverse effects. 


\section{MARICHA ${ }^{4}$}

Table 3: Properties

\begin{tabular}{|l|l|}
\hline Rasa & Katu \\
\hline Guna & Laghu, ruksha, teekshna \\
\hline Virya & Ushna \\
\hline Vipaka & Katu \\
\hline Doshaghnata & KV hara \\
\hline Karma & Deepana, Shoolaprashamana, Krimighna \\
\hline
\end{tabular}

Maricha is considered to have antitoxic properties, as studies have shown that maricha kashaya is able to reverse the toxicity which was induced by Vatsanabha in an experimental study.

Black pepper has an effect like a water pill or diuretic. Taking black pepper might decrease how well the body gets rid of the lithium.

Black pepper contains volatile compounds, oleoresins and alkaloids which create a powerful plant, particularly for reducing Oxidative stress. Another review of its powerful benefits states that the key alkaloid components of Piper nigrum that is, piperine, assist in cognitive brain functioning, boost nutritive absorption and improve gastrointestinal functionality. A 1993 lab study found that Maricha protected the liver from damage caused by oxidative substances and helped the liver maintain its level of glutathione (GSH), an important antioxidant that is often depleted by damage to liver function.

It was found that piperine inhibited the increased level of serum GPT and GOT in a dose-dependent manner in a hepato-toxicity model of mice caused by D-galactosamine. Thus, it was concluded that Piper nigrum possesses potential hepato-protective activity due to the presence of piperine alkaloids and have great therapeutic potential in the treatment of liver ailments.
Piperine has shown bioavailability enhancing effects on many therapeutically important drugs and nutrients. Piperine increases the absorption of many drugs and nutrients from the gastrointestinal tract by various mechanisms. It alters the membrane dynamics and increases permeability at the site of absorption. Therefore, piperine is known as a bioavailability enhancer and a potent drug's metabolism inhibitor.

\section{HARIDRA ${ }^{5}$}

Haridra (Curcuma longa) is a potent as well as a widely prescribed drug in Ayurveda used as an antioxidant and possesses various beneficial properties such as anti-inflammatory, anti-allergic, antiseptic, antidiabetic, blood cleansing etc.

Helps to protect the liver and prevents liver disorders as it maintains the level of liver enzymes, it also protects the liver cells against damage caused by free radicals as it has antioxidant, anti-inflammatory and hepatoprotective activities.

Curcumin and related phenolics have been associated with the inhibition of lipid peroxidation, free radical formation and DNA damage under the role of radical scavengers and/or antioxidants.

Levels of lipid peroxidation, serum biomarker enzymes, liver MDA, hydroxyproline and liver antioxidants were correspondingly modified after curcumin treatment.

Table 4: Properties

\begin{tabular}{|l|l|}
\hline Rasa & Tikta, Katu \\
\hline Guna & Ruksha, Laghu \\
\hline Virya & Ushna \\
\hline Vipaka & Katu \\
\hline Doshaghnata & Tridoshahara \\
\hline Karma & Pramehahara, vishanut, Pitta rechaka, twakdoshajit, aruchinashini \\
\hline
\end{tabular}


4. TAMRA BHASMA ${ }^{5}$-Tamra bhasma is obtained by oxidizing and heating the copper metal with different herbal juices including aloe vera gel and lemon juice. Tamra bhasma is blessed with several extraordinary healing properties like antacid, expectorant, mild laxative, digestive stimulant, fat burner, it promotes a proper flow of pitta dosha due to its cholagogue action. It stimulates the bile secretion from the liver and gall bladder, which is considered the main target site of tamra bhasma to act upon. It eases digestion and helps in maintaining healthy skin and body.
Tamra bhasma has a scraping quality and it also acts as a fat burner that aids in controlling obesity. Hence, it's widely used in treating high cholesterol. Ayurveda advocates the use of tamra bhasma in Yakrit-pliha vriddhi, it gradually reduces the size of the liver and spleen by alleviating inflammation

Tamra bhasma is a mild laxative, it eases bowel movement, stimulates bile salts from the liver and softens hard bowels thereby providing relief in problems related to irregular, hard or inconsistent bowel.

Table 5: Properties

\begin{tabular}{|l|l|}
\hline Rasa & Kashaya, madhura, tikta, amla \\
\hline Guna & Laghu, ruksha, tikshna \\
\hline Virya & Ushna \\
\hline Vipaka & Katu \\
\hline Doshaghnata & KP shamaka \\
\hline Karma & Lekhana, deepana, medohara \\
\hline
\end{tabular}

5.JAYAPALA ${ }^{6}-$ Croton tigilium Linn. (Euphorbiaceae) commonly known as jamalagota, jayapala is an organic irritant herb that is used for treating various ailments. The croton oil is pale yellow, viscid with a nauseous odour and bitter acrid taste. It contains irritant phytoconstituents such as phorbol esters and crotonic acid which may be responsible for its severe purgative action. In Ayurvedic classics, it is explained under the category of Upavisha, used in certain formulations recommended for liver diseases.

Croton tigilium is well known for its purgative property; furthermore, phorbol esters and crotonic acid were reported as responsible phytochemicals. It is reported in certain previous studies that shodana procedure with godugdha reduces the number of

Table 6: PROPERTIES

\begin{tabular}{|l|l|}
\hline Rasa & Katu \\
\hline Guna & Guru, Ruksha, Teekshna \\
\hline Virya & Ushna \\
\hline Vipaka & Katu \\
\hline Doshaghnata & Kaphapittashamaka \\
\hline Karma & Deepana, Krimihara, rechaka, Jataraamaya shodhana, Garavisha \\
\hline
\end{tabular}


5. SNUHI KSHEERA ${ }^{7}$ - Euphorbia nerifolia belonging to the family Euphorbiaceae is one of the potent and useful drugs in Ayurvedic pharmacopoeia. Based on the synonyms depicted in Nighantus, it can be proclaimed that the plant with the straight stem being circular in appearance, full of latex, leaves are shaped like the blade of the sword, with sharp twin spines (Vyaghranakha) can be used as identifying characteristic feature for snuhi. The latex of E. nerifolia is acrid, laxative, pungent and good for abdominal tumours and leucoderma. It is also used as a purgative, rubefacient, alexipharmic, carminative, expectorant, to treat jaundice, renal calculi etc., It is used as a drastic purgative in the enlargement of liver and spleen, general anasarca etc conditions. It is considered as shreshta teekshna virechaka, does sheegra mala bhedana in krura koshta

Table 7: Properties

\begin{tabular}{|l|l|}
\hline Rasa & Katu \\
\hline Guna & Laghu, teekshna \\
\hline Virya & Ushna \\
\hline Vipaka & Katu \\
\hline Doshaghnata & KV shamaka \\
\hline Rogaghnata & $\begin{array}{l}\text { Shoola, ashteela, adhmana, kaphaja gulma, udara, unmada, } \\
\text { kushta, arsha, shotha etc }\end{array}$ \\
\hline
\end{tabular}

\section{DISCUSSION}

The formulation taken for review is described in Udara roga parakarana of Bhaishajya Ratnavali, also in other rasashastra classical texts like Rasendra sara sangraha, Rasachandamshu, Rasakamadhenu, Yogaratnakara, Rasarajasundara, Bruhatyogatarangini and Rasamanjari, all depicting similar drug design.

Chikitsa sutra of Jalodara is "Nitya virechana", to break up the sanga of all the doshas and retain fluid and separate them, virechana is necessary. Yakrit is the moola sthana of rakta. Raktapitta has ashrayaashrayisambandha, hence for the elimination of pittadosha, purgation is the best treatment. Virechana also decreases abdominal girth and edema by decreasing fluid in the abdominal cavity. Jalodarari rasa maintains liver function and promotes balance as well as a healthy digestive system, its efficacy is also enhanced by the action of two potent purgative ingredients that is Jayapala and Snuhi ksheera.

- Jayapala, its main content, which acts as Pitta virechana and acts on Yakrit. Because of its attributes, it is liable to have actions to increase the jatharagni and dhatvagni, it even acts as avaranahara and helps in srotomukhavishodhana thus tackling the root pathology of jalodara. It contains certain irritant phytoconstituents such as phorbol esters and crotonic acid which may be responsible for its severe purgative action. The plant possesses anticancer, antioxidant activity, smooth muscle relaxant activity, purgative, analgesic, anti-inflammatory and inhibit HIV induced cytopathic effect. From the review, we can say that Jayapala can act as Antidermatophytic, Antioxidant, Hepatoprotective, anticonvulsant, antimicrobial, anticancerous drug. Thus, Jayapala has immense practical applicability in biomedicine, but more clinical trials should be conducted to support its therapeutic uses.

- The metallic component Tamra bhasma is an effective agent for renewing vitality. It acts like nectar, 7has powerful antioxidant properties and is used for relieving kidney disorders, liver and other digestive disorders. Tamra bhasma one of the ingredients has been proven to be hepatoprotective and also beneficial in yakritpleeha vriddhi (hepato-spleen enlargement) and is Antihyperlipidemic. Due to its katu ushna 
guna, it is having actions like Lekhana thereby beneficia lin fatty liver disease, also by virtue of its avaranahara and scraping quality helps to remove avarana in the ambuvaha and raktavaha srotas. It also stimulates bile secretion from the liver and gall bladder.

- Pippali is having katuushna guna, anushna virya able to tackle jataraghni and dhatvagni mandya, also have properties like aruchihara and is termed as yakritpleehaamayahara in charaka samhita. It enhances the absorption of curcumin and its compounds by the body.

- Maricha has ushna, katu properties, deepana, pachana, Mutra rechaka (Diuretic) properties, enhancing the bioavailability of the drugs.

- Haridra is having properties like antiseptic and is able to remove or clear infections if it is the impending cause for the ascites, antiinflammatory, anti-cancerous in action as well. By the virtue of tikta-katu rasa, ushna veerya, katu vipaka and laghu ruksha guna, haridra removes the blockage in the liver and restores the haematopoietic functions. It also regularizes the fat metabolism and detoxifies the nutrients passing through it. Thereby rectification of liver functions leads to the destruction of free circulating fats which are responsible for the manifestation of Prameha.

- Snuhi ksheera, the bhavana dravya for jalodarari rasa has properties to alleviate kapha and vata, also has shoolaghna and shothahara properties by which it gives relief in symptoms like pain and sense of fullness of the udara. It also has visha and amahara properties by which it aids to wash away the toxins from the body, and parallelly maintains the nutrition levels required for the body tissues.

As most of the ayurvedic physicians take up conditions of chronic liver disease and ascites and follow the protocol of nitya virechana which is authentic and gives miraculous results.

Jalodarari rasa can be effectively employed as an alternative to Gomutra haritaki, which is a strong purgative used in ascites, but has unpleasant taste and odour and needs more convincing to the patient for its excess quantity intake, but in the case of Jalodarari rasa, it can be given in very small amount as it is having rasaoushadis which work better and quicker in low doses and also there is no issue in relation to palatability as it is in tablet form, ease to instil, pleasant in appearance but has an enormous effect on ascites. Though the new scholars have mentioned the dose for jalodarari ras to be taken in 1-2 ratti, incases of uttama bala and uttama satva dose can be increased on basis of the patient's condition and yukti of the physician. Thus, jalodarari rasa can be implemented as an effective hepatoprotector and can be instilled in the routine clinical practice, thereby with this aim the entire review was undertaken.

\section{CONCLUSION}

Ayurveda has been used to treat several liver ailments, but its efficiency is poorly documented by means of scientific studies. A high number of Ayurveda liver tonics has been prescribed for chronic liver disease and GI disorders by all systems of doctors.

The ayurveda treatment outcome in Ascites is better compared to the modern system of medicine. It needs integration for a better outcome. So public participation and awareness for ayurveda treatment in chronic liver diseases are required along with proper training and skill development of Ayurveda physicians. More evidence will create hope for Ascites patients. Jalodarari rasa improves overall good health by balancing all three Dosha. The drug does not have appreciable toxicological effects on the brain, liver and kidney. This remedy is also known as a natural liver detoxifying and fatty liver remedy. It promotes balance and maintains liver function as well as a healthy digestive system. Jalodarari rasa does the Shoshan (assimilation) of different excess Snigdha dravyas (unctuous substances) present in the body. It also does the Pachan (digestion) of Drava (liquid) and Kleda (clammy) and does the Raktavardhana (purifies blood). It reduces Dravatva, Snigdhatva in Meda dhatu. Self-medication of the 
drug should be strictly avoided to overcome any untoward effects.

\section{REFERENCES}

1. Bhaishajya Ratnavali, Govindas, Udararoga Chikitsa Prakarana, Ambikadattashastri, Chaukhamba prakashan (U.P) edition,2016;761.

2. Acharya Agnivesha, Charaka Samhita, Ayurveda Deepika Commentary of Chakrapani, Edited by Vaidya Yadavji Trikamji Acharya, Chaukambha Krishnadas Academy, Varanasi Year of reprint:2019, Sutra Sthana, Chapter 25, verse 40,339pp

3. Dept of Ayush. CCRAS.Database on medicinal plants used in Ayurveda and siddha, prof G.S. Levekar et, al, New Delhi,2007, vol3,472pp

4. Dept of Ayush. CCRAS.Database on medicinal plants used in Ayurveda and siddha, prof G.S. Levekar et, al, New Delhi,2007, vol5,187pp

5. Dept of Ayush. CCRAS.Database on medicinal plants used in Ayurveda and siddha, prof G.S. Levekar et, al, New Delhi,2007, vol1,152pp

6. Sri Vagbhatacharya, Rasa Ratna Samuchaya, Edited by Indradev Tripathi,3rd Edition, Varanasi, Chaukambha Sanskrit bhavan,2006,5th chapter, verse 46,57pp.

7. J.L.N Shastry, Dravya guna vignana, Chaukambha orientalia, 2005 edition, vol 2, 937pp

8. Dept of Ayush. CCRAS.Database on medicinal plants used in Ayurveda and siddha, prof G.S. Levekar et, al, New Delhi,2007, vol4,514pp

\section{Source of Support: Nil Conflict of Interest: None Declared}

How to cite this URL: Ayesha Zama \& Ravi. R. Chavan: Critique On Jalodarari Rasa - A Mighty Hepatoprotection. International Ayurvedic Medical Journal \{online\} 2021 \{cited November 2021\} Available from: http://www.iamj.in/posts/images/upload/2756_2763.pdf 